\title{
UJI ANTIBAKTERI JAMUR ENDOFIT DARI TUMBUHAN MANGROVE Sonneratia alba YANG TUMBUH DI PERAIRAN PANTAI TANAWANGKO
}

\author{
(Antibacterial Activity Study of Endophytic Fungi Derived from Sonneratia alba \\ Mangrove Growing on Tanawangko Waters)
}

\author{
Yohanis Nawea $^{{ }^{*}}$, Remy E.P Mangindaan ${ }^{1}$, Robert A. Bara ${ }^{1}$
}

1. Program Studi IImu Kelautan, Fakultas Perikanan dan IImu Kelautan, Universitas Sam Ratulangi, Manado.

*e-mail : randinawea@gmail.com

Endophytic fungi are type of fungi that live inside the plant tissues without causing any disease to the plants. In this research we used mangrove Sonneratia alba as a source of endophytic fungi. The antibacterial test method was using the modified Kirby-Bauer method. The fungus that shows strong antibiotic activity was statically cultivated on rice medium for 10 days incubation. Induction of Staphylococcus aureus carried on the fungal isolate that shows strongest antibacterial activity. The purpose of these inductions into the fungal culture is to trigger the studied fungus to produce a specific compound through its silent biosynthetic pathway. The incubation process was terminated by maceration by adding $96 \%$ ethanol into the culture,. Continued by partitioned methods by using ethyl acetate, $n$-hexane, ethanol and water solvents to obtain $\mathrm{n}$-hexane, ethanol and waterfractions. Each fraction was tested their antibiotic activity by using the method described above. Nine fungal isolates of mangrove $S$. alba were isolated in this study. Five isolates showed antibacterial activity against both Staphylococcus aureus and Escherichia coli. Three of these isolates (PTWSAA1.1, 1.2 and 1.3) showed strong activity against both bacterial test. These fungal isolates were cultivated on rice media followed by extraction and partition procedures. The antibacterial activity test of each fraction of the fungal isolates showed only ethanol fraction shows antibacterial activity, concluded the active antibacterial compound of three endophytic fungi derived from $S$. alba mangrove are semipolar.

Keywords: endophyte, Sonneratia alba, antibiotics, Staphylococcus aureus, Escherichia coli.

Jamur endofit merupakan jamur yang hidup di dalam jaringan tumbuhan tanpa memperlihatkan timbulnya penyakit pada tumbuhan tersebut. Pengujian antibakteri menggunakan metode Kirby-Bauer yang dimodifikasi. Jamur yang memperlihatkan aktivitas antibiotik yang kuat dikultivasi statis dalam media nasi selama 10 hari Induksi bakteri S. aureus dilakukan pada isolat yang menunjukkan aktivitas tertinggi. Tujuan pemberian bakteri pada kultur yaitu memicu jamur untuk menghasilkan senyawa tertentu melalui jalur biosintesis senyap (Silence Biosynthetic Pathway) pada jamur tersebut. Proses inkubasi dihentikan dengan cara maserasi dengan menambahkan etanol $96 \%$ ke dalam kultur selama 24 jam. selanjutnya dipartisi dengan pelarut etil asetat, n-heksan, etanol dan air untuk memperoleh fraksi n-heksan, etanol dan air. Tiap fraksi ini diuji kembali aktivitas antibiotiknya dengan menggunakan metode tersebut di atas. Hasil penelitian ini diperoleh sembilan isolat jamur dari mangrove $S$. alba. Lima isolat menunjukkan aktivitas antibakteri terhadap bakteri S.aureus dan E. coli Tiga isolat akar (PTWSAA1.1, 1.2 dan 1.3) menunjukkan aktivitas yang kuat terhadap kedua bakteri uji. Ketiga isolat jamur dikultivasi statis dalam media nasi dilanjutkan dengan ekstraksi dan partisi. Pengujian aktivitas antibakteri tiap fraksi ketiga isolat jamur memperlihatkan hanya fraksi etanol yang menunjukkan aktivitas penghambatan, Hal ini menunjukkan bahwa senyawa aktif antibakteri dari ketiga jamur endofit merupakan senyawa yang bersifat semipolar.

Kata Kunci : jamur endofit, Sonneratia alba, antibakteri, S.aureus, E. coli. 


\section{PENDAHULUAN}

Jamur endofit merupakan jamur yang hidup di dalam jaringan tumbuhan tanpa memperlihatkan timbulnya penyakit pada tumbuhan tersebut. Jamur ini memiliki potensi yang besar untuk dieksploitasi dan menghasilkan senyawa-senyawa alami baru yang bermanfaat di bidang medis, pertanian, dan industri. Strobel et al. (2004). mengungkapkan 300 ribu spesies tumbuhan tingkat tinggi dibumi dengan masing-masing individu tumbuhan menjadi inang dari jamur endofit. Belakangan ini beberapa produk bioaktif baru berhasil diisolasi dan diidentifikasi. Senyawa-senyawa ini bukan hanya memiliki struktur dasar yang unik dan tetapi juga aktivitas biologis tinggi (Debbab et al. 2009; Aly 2010; Ibrahim et al. 2010; Aly et al. 2011 a, b; Debbab et al. 2011; Debbab et al. 2012; Ebrahim et al. 2012; Bara et al. 2013.

Resistensi antibiotik merupakan problematika di bidang kesehatan. Berbagai jenis kuman patogen berkembang menjadi resisten terhadap satu atau beberapa jenis antibiotika. Terdapat dua hal mendasar terkait dengan terjadinya resistensi bakteri terhadap antibiotik yaitu kemampuan bakteri untuk membentuk pertahanan diri terhadap antibiotik secara cepat mati dan ketidaktepatan dosis dalam tindakan.

Mangrove Sonneratia alba berkemampuan untuk menghambat bakteri karena sejak beberapa abad yang lalu, masyarakat pesisir di berbagai tempat di Indonesia secara tradisional telah memanfaatkan mangrove sebagai obat-obatan (getah untuk antifertilitas atau mencegah kehamilan, salep dari biji untuk obat penyakit cacar atau penyembuh luka. Karena itu sangat dimungkinkan jamur endofit dari mangrove $S$. alba ini berpotensi untuk dikembangkan sebagai bahan obat-obatan.

\section{METODE PENELITIAN}

\section{Isolasi jamur endofit}

Sampel daun, ranting dan akar mangrove S. alba asal Perairan Tanawangko (1²4'29.73" LU; $124^{\circ} 41^{\prime} 46.26^{\prime \prime}$ BT) yang telah diambil, dipotong kira-kira $5 \mathrm{~cm}$ dan dicelup dalam larutan etanol $70 \%$ selama 30 detik untuk menghindari kontaminasi silang mikroba epifit. Setelah itu dipotong-potong dengan ukuran sekitar $1 \mathrm{~cm}$ menggunakan gunting steril. Potongan ini selanjutnya ditanam pada media agar singkong (Cassava agar) di dalam cawan petri. Tiap cawan berisi 4 potongan sampel, lalu ditutup kemudian di simpan pada suhu kamar $\left(25^{\circ} \mathrm{C}\right)$. Setelah 2-3 hari terlihat pertumbuhan jamur di sekitar sampel.telah diletakkan di media agar.

Miselia jamur yang tumbuh pada media agar singkong kemudian secara bertahap diisolasi satu-persatu dengan menggunakan kawat ose steril dan dipindahkan ke media singkong steril pada cawan petri lainnya. Jamur endofit yang telah tumbuh selanjutnya dinokulasi ke dalam media agar baru tanpa pemberian antibiotik.

\section{Skrining Aktivitas Antibiotik dari Jamur Endofit}

Miselia jamur endofit yang sudah tumbuh diambil sebagian dengan menggunakan sedotan steril dan dipindahkan ke media kombinasi yang sudah diolesi bakteri uji ( $S$. aureus dan E. coli). Selanjutnya petri yang berisi jamur endofit diinkubasi dalam suhu $25^{\circ} \mathrm{C}$ selama 1-2 x 24 hari. Setelah itu diamati aktivitas antibiotik terhadap S. aureus dan E. coli.

\section{Kultivasi dan Ekstraksi Jamur pada Media Nasi}

Kultur jamur pada media nasi secara statik selama 10 hari pada suhu ruang. Setelah pertumbuhan misilia jamur endofit mencapai bagian dasar dari labu erlenmeyer dilakukan ekstraksi. Proses ini dilakukan dengan menambahkan etanol $95 \%$ sampai 
semua nasi terendam lalu diaduk dengan shaker selama selama 24 jam. Rendaman selanjutnya disaring kemudian di evaporasi menggunakan Rotary vacuum evaporator pada suhu $40^{\circ} \mathrm{C}$.

\section{Partisi}

dilakukan pada ekstrak yang menunjukan aktivitas antibakteri yang kuat. Prosedur kerja partisi dilakukan dengan menambahkan air dan etil asetat pada ekstrak kemudian larutan yang terbentuk dimasukkan ke dalam corong pisah (separotory funnel) lalu dikocok dan didiamkan selama 10 menit, sehingga akan terlihat 2 lapisan yaitu fraksi air dan fraksi etil asetat. fraksi etil asetat kemudian dievaporasi kemudian difraksinasi kembali dengan n-heksan dan etanol $70 \%$ (perbandingan 1:1) dalam corong pisah kemudian dikocok serta didiamkan lagi selama 10 menit sehingga nampak adanya 2 lapisan yaitu fraksi heksan dan fraksi etanol. Kedua fraksi kemudian dievaporasi untuk menguapkan pelarut. Ketiga fraksi (fraksi n-heksan, etanol dan air) diuji aktivitasnya kembali untuk mengetahui lokasi senyawa aktif yang berada.

\section{HASIL DAN PEMBAHASAN}

Hasil pembiakan jamur endofit yang berasal dari akar, ranting dan daun mangrove Sonneratia alba yang diambil dari lokasi pantai Tanawango menghasilkan 9 spesies jamur yaitu tiga dari isolat daun, dua dari isolat batang dan empat dari isolat akar. Pada bagian tanaman yang berbeda dapat diisolasi jamur endofit yang bervariasi/berbeda-beda bentuk koloni dan perbedaan warna pada miselia. Isolat jamur yang tumbuh pada bagian akar memiliki karakteristik meselia berwarna hitam dan kuning, sedangkan pada bagian ranting isolat jamur memiliki miselia dengan karakteristik warna kuning dan putih dan pada bagian daun berwarna kuning dan putih. Pada bagian isolat daun dan isolat akar ada isolat yang memeiliki kesamaan warna dan karakteristik bentuk yang sama dapat dilihat pada Gambar 1.

A.
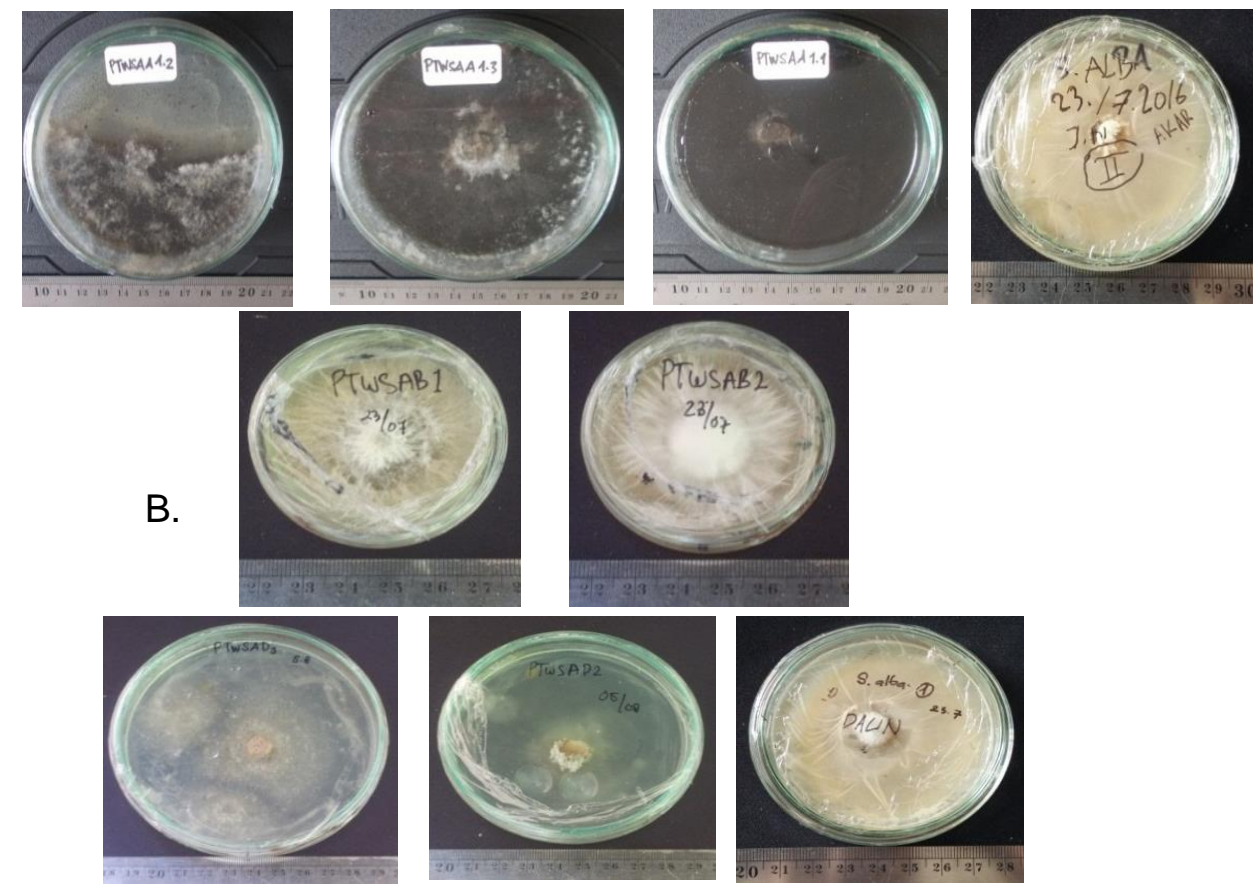

Gambar. 1. Morfologi koloni isolat jamur endofit dari akar (A), batang (B) dan daun (C) mangrove $S$. alba. 
1. Hasil pengujian awal isolat jamur pada bakteri S. aureus dan E. coli Hasil pengujian dari 9 isolat jamur endofit yang diujikan pada bakteri $S$. aureus dan E. coli, menunjukkan adanya zona hambat yang cukup bermakna pada isolat jamur asal akar dan daun sedangkan isolat jamur asal ranting mangrove tidak memperlihatkan adanya daya hambat pada kedua bakteri uji. Hal ini mungkin dapat disebabkan jamur endofit yang diisolasi dari akar dan isolat daun mampu menghasilkan senyawa-senyawa aktif antibakteri, kemungkinan besar isolat jamur endofit dari ranting mangrove tidak memproduksi metabolit sekunder antibakteri. Hasil pengamatan aktivitas antibakteri pada isolat jamur endofit selama 4-24 jam pengamatan tersaji pada Tabel 1.

Tabel. 1. Uji aktivitas antibiotik isolat Jamur endofit $S$. alba terhadap bakteri S.aureus dan E. coli.

\begin{tabular}{|c|c|c|c|c|c|c|c|c|}
\hline \multirow[t]{2}{*}{ Kode isolat } & \multicolumn{4}{|c|}{$\begin{array}{c}\text { S. aureus } \\
\text { Pengamatan hari ke- }\end{array}$} & \multicolumn{4}{|c|}{$\begin{array}{c}\text { E. coli. } \\
\text { Pengamatan hari ke- }\end{array}$} \\
\hline & 1 & 2 & 3 & 4 & 1 & 2 & 3 & 4 \\
\hline \multicolumn{9}{|l|}{ Isolat daun } \\
\hline 1. PTWSAD1 & - & - & - & - & + & + & + & + \\
\hline 2. PTWSAD2 & + & + & - & - & + & + & + & + \\
\hline 3. PTWSAD3 & - & - & - & - & - & - & - & - \\
\hline \multicolumn{9}{|l|}{ Isolat batang } \\
\hline 4. PTWSAR1 & - & - & - & - & - & - & - & - \\
\hline 5. PTWSAR2 & - & - & - & - & - & - & - & - \\
\hline \multicolumn{9}{|l|}{ Isolat akar } \\
\hline 6. PTWSAA1.1 & + & + & + & + & + & + & + & + \\
\hline 7. PTWSAA1.2 & + & + & + & + & + & + & + & + \\
\hline 8. PTWSAA1.3 & + & + & + & + & + & + & + & + \\
\hline 9. PTWSAA.2 & - & - & - & - & - & - & - & - \\
\hline
\end{tabular}

\section{Ekstraksi dari Jamur Endofit pada Media Nasi}

Dari pengujian awal antibakteri dari 9 isolat jamur di atas, diputuskan isolat jamur endofit yang terdapat pada bagian akar PTWSAA1.1,PTWSAA1.2, PTWSAA1.3 dikultur pada media nasi untuk mendapatkan biomassa ekstrak jamur yang lebih banyak untuk diteliti lebih lanjut. Jamur isolat akar (PTWSAA1.1, PTWSAA1.2 dan PTWSAA1.3) ditumbuhkan di dalam media nasi kemudian diinkubasi statik pada suhu kamar selama 10 hari.
Induksi bakteri $S$. aureus dilakukan pada isolat PTWSAA1.2 (PTWSAA1.2+S.a).

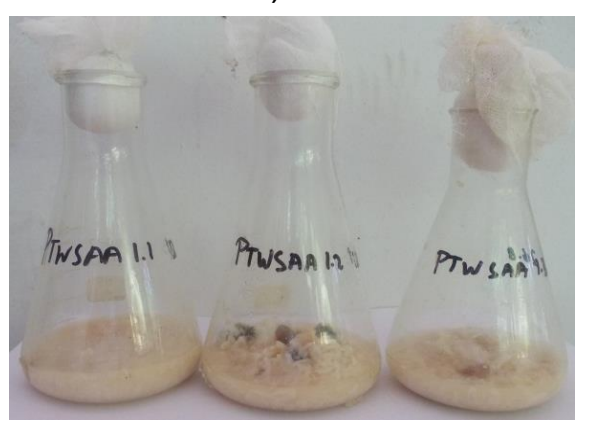

Gambar. 2 Kultivasi jamur endofit pada media nasi. 
Tujuan pemberian bakteri pada kultur yaitu memicu jamur untuk menghasilkan senyawa tertentu melalui jalur biosintesis senyap (Silence Biosynthetic Pathway) pada jamur tersebut. Proses inkubasi dihentikan dengan cara maserasi dengan menambahkan etanol $96 \%$ ke dalam kultur selama 24 jam. Ekstrak kemudian disaring, filtrat yang diperoleh dievaporasi untuk menguapkan pelarut. Keempat ekstrak pekat kemudian diujikan kembali aktivitas antibakterinya

\section{Pengujian aktivitas antibakteri dari ekstrak}

Setelah diinkubasi pada temperatur $37^{\circ} \mathrm{C}$ dalam inkubator selama 1x24 jam, keempat ekstrak menunjukkan aktivitas antibakteri terhadap bakteri $S$. aureus dan E. coli dengan terlihatnya diameter zona terang di sekitar ekstrak. Gambar 3 memperlihatkan zona hambat di sekitar keempat ekstrak isolat jamur endofit dan kontrol positif terhadap kedua bakteri uji. Hasil pengukuran diameter zona hambat keempat isolat jamur endofit tersaji dalam Tabel 2.

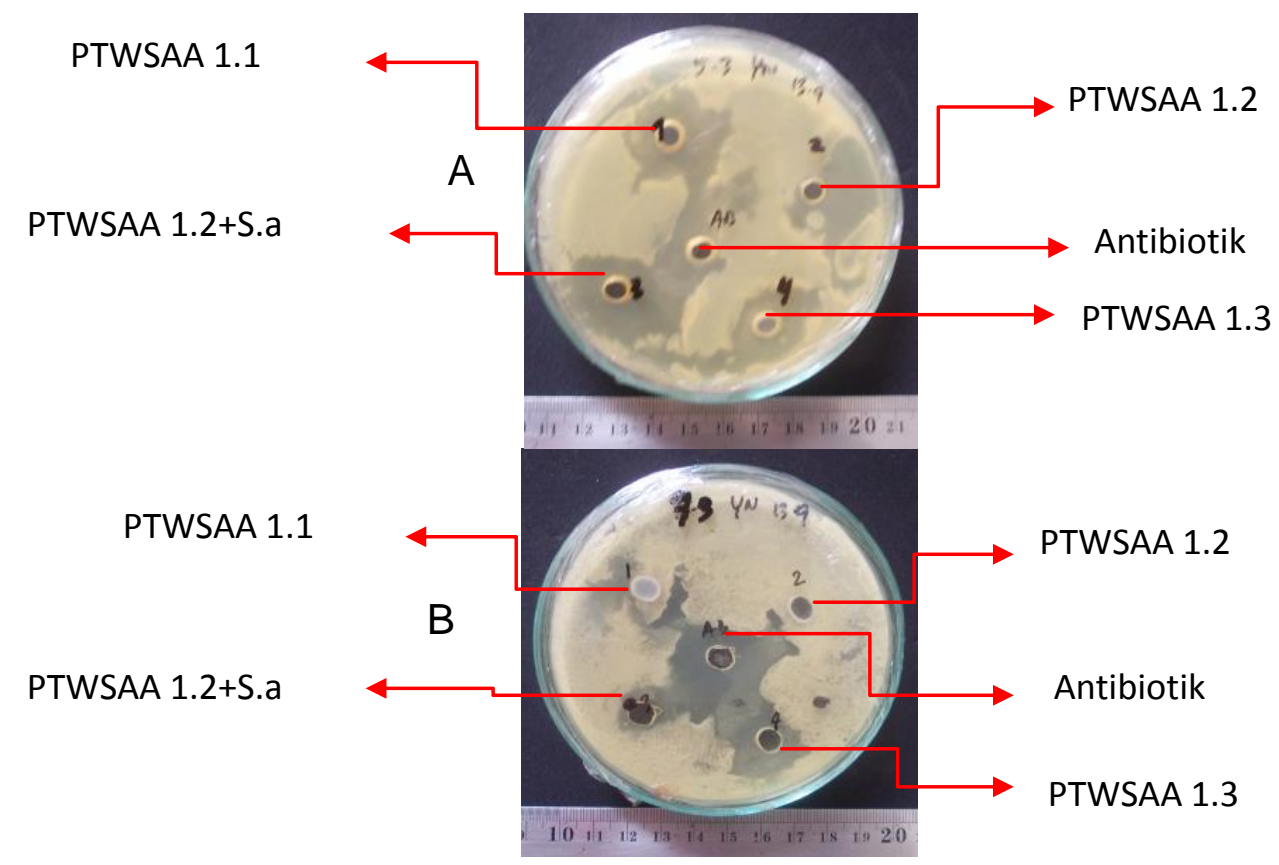

Gambar 3. Uji ekstrak jamur pada: bakteri S. aureus (A) dan E. coli (B). 
Tabel. 2. Pengukuran diameter zona hambat ekstrak jamur terhadap bakteri uji.

\begin{tabular}{lllllllllc}
\hline No. & Kode isolat jamur & \multicolumn{4}{c}{ S. aureus $(\mathrm{mm})$} & \multicolumn{3}{c}{ E. coli $(\mathrm{mm})$} \\
\cline { 3 - 10 } & & 1 & 2 & 3 & rata-rata & 1 & 2 & 3 & rata-rata \\
\hline 1. & PTWSAA1.1 & 25 & 20 & 24 & $23.0 \pm 2.6$ & - & - & - & - \\
2. & PTWSAA1.2 & 21 & 15 & 20 & $18.7 \pm 2.6$ & - & - & - & - \\
& & & & & & & & & \\
3. & PTWSAA1.2+S.a & 25 & 21 & 20 & $22.0 \pm 3.2$ & 15 & 17 & 17 & $16.3 \pm 1.2$ \\
& & & & & & & & & \\
4. PTWSAA1.3 & 21 & 21 & 23 & $21.7 \pm 1.2$ & 25 & 22 & 25 & $24.0 \pm 1.7$ \\
5. & ANTIBIOTIK & 30 & 25 & 26 & $27.0 \pm 1.6$ & 25 & 29 & 29 & $27.7 \pm 2.3$
\end{tabular}

Hasil pengamatan memperlihatkan hanya dua ekstrak yang menunjukkan aktivitas pada kedua bakteri uji yaitu ekstrak jamur endofit PTWSAA 1.2+S.a yang ditambahkan bakteri $S$. aureus dan ekstrak jamur endofit PTWSAA 1.3, sedangkan ekstrak jamur endofit PTWSAA 1.1 dan PTWSAA 1.2 hanya memperlihatkan aktivitas yang lebih spesifik terhadap bakteri $S$. aureus. Induksi bakteri $S$. aureus pada isolat PTWSAA1.2+ S.a memberikan pengaruh terhadap zona hambat terhadap pada kedua bakteri uji.

Penambahan bakteri pada kultur jamur tidak meningkatkan aktivitas antibakteri ekstrak yang dihasilkan. Hal ini berbeda dengan penelitian Ola et al, (2013) yang mengungkap kultivasi bersama jamur endofit Fusarium tricintum dengan bakteri Bacillus subtilis memicu jamur yang dipelajari menghasilkan senyawa baru dengan sifat antibakteri yang tidak ada pada kultur tunggal jamur tersebut.

\section{Partisi dan uji aktivitas antibiotik}

Partisi dilakukan untuk melihat pada fraksi mana pada ekstrak jamur yang memberikan aktivitas zona hambat pada bakteri uji $S$. aureus dan E. coli. Hasil dari partisi ekstrak didapatkan tiga fraksi yaitu fraksi air, fraksi etanol dan fraksi n-heksan.

Ketiga fraksi yang telah didapatkan diuji aktivitas antibakterinya kembali untuk melihat pada fraksi mana yang mengandung senyawa yang bertanggung jawab terhadap aktivitas antibakteri pada keempat ekstrak terhadap bakteri uji $S$. aureus dan bakteri E. coli. Gambar 5 memperlihatkan adanya zona hambat di sekitar fraksi etanol isolat jamur PTWSAA1.1 serta kontrol positifnya. Hasil pengukuran diameter zona hambat fraksi isolat jamur PTWSAA1.1 terhadap $S$. aureus dan bakteri $E$. coli dapat dilihat pada Tabel 3. Hasil penelitian pada ekstrak ini menunjukkan bahwa hanya pada fraksi etanol yang menunjukkan adanya aktivitas zona hambat sedangkan pada fraksi air dan fraksi n-heksan tidak memperlihatkan adanya zona hamba 

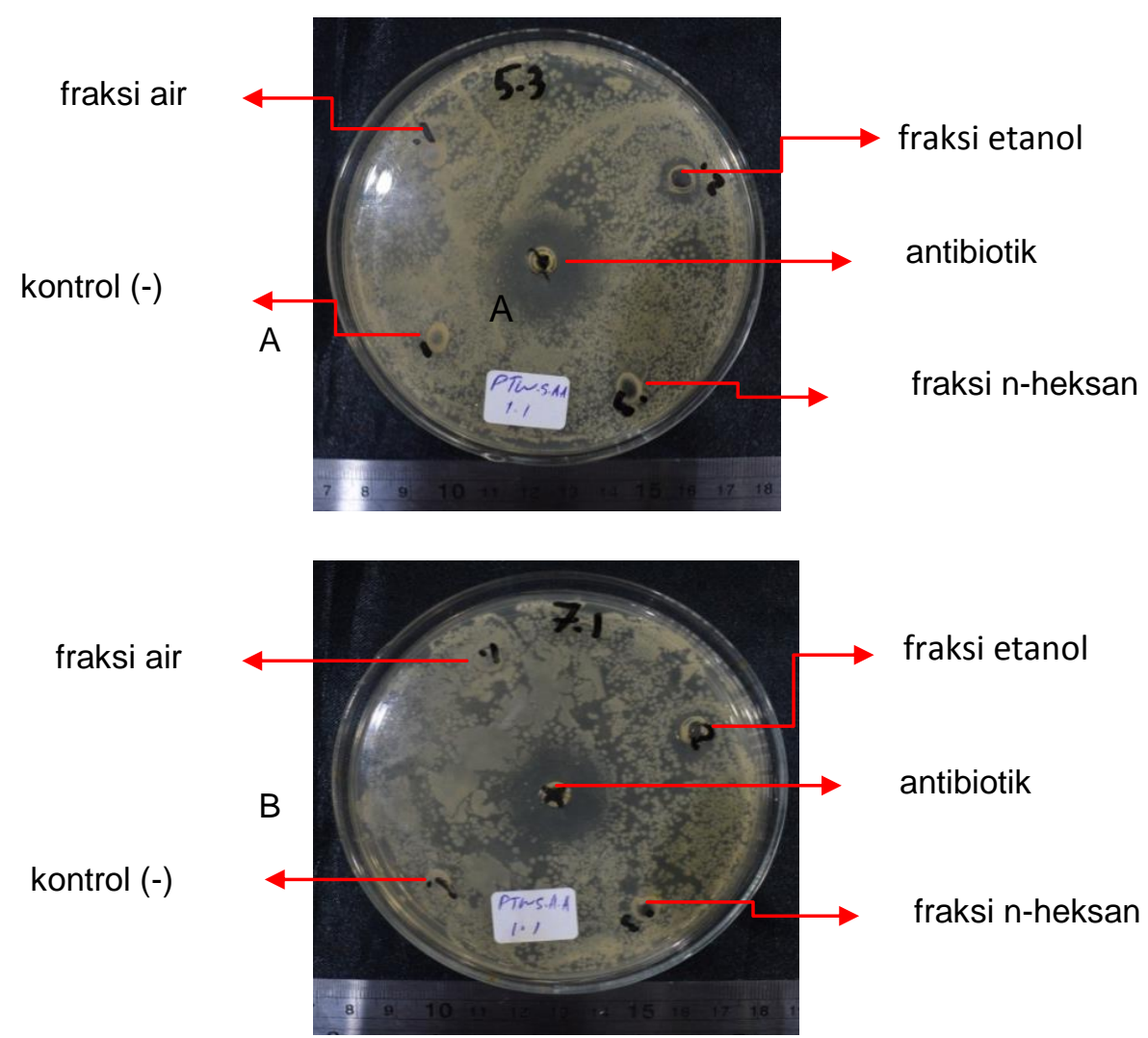

Gambar 5. Hasil pengujian aktivitas anti bakteri fraksi ekstrak PTWSA 1.2 terhadap bakteri $S$. aureus $(\mathrm{A})$ dan bakteri $E$. coli (B).

Tabel. 3. Pengukuran daya hambat jamur pada fraksi ekstrak jamur PTWSAA 1.1 terhadap bakteri S. aureus dan E. coli.

\begin{tabular}{lllllllll}
\hline PTWSAA1.1 & \multicolumn{4}{c}{ S. aureus $(\mathrm{mm})$} & \multicolumn{4}{c}{ E. coli $(\mathrm{mm})$} \\
\cline { 2 - 9 } & 1 & 2 & 3 & rata-rata & 1 & 2 & 3 & rata-rata \\
\hline fraksi air & - & - & - & - & - & - & - & - \\
fraksi etanol & 13 & 13 & 12 & $12.7 \pm 0.6$ & 13 & 12 & 13 & $12.7 \pm 0.6$ \\
fraksi n-heksana & - & - & - & - & - & - & - & - \\
kontrol negatif & - & - & - & - & - & - & - & - \\
antibiotik & 25 & 25 & 25 & $25.0 \pm 0.0$ & 25 & 25 & 25 & $25.0 \pm 0.0$ \\
\hline
\end{tabular}

Gambar 6 memperlihatkan adanya zona hambat di sekitar fraksi etanol isolat jamur PTWSAA 1.2 dan kontrol positifnya. Hasil pengujian aktivitas antibakteri fraksi ekstrak PTWSAA 1.2 terhadap $S$. aureus dan bakteri E. coli . dapat dilihat pada Tabel 4. Hasil penelitian pada isolat jamur ini menunjukkan bahwa hanya pada fraksi etanol yang memperlihatkan adanya zona hambat sedangkan pada fraksi air dan fraksi n-heksan tidak memperlihatkan adanya zona hambat. 


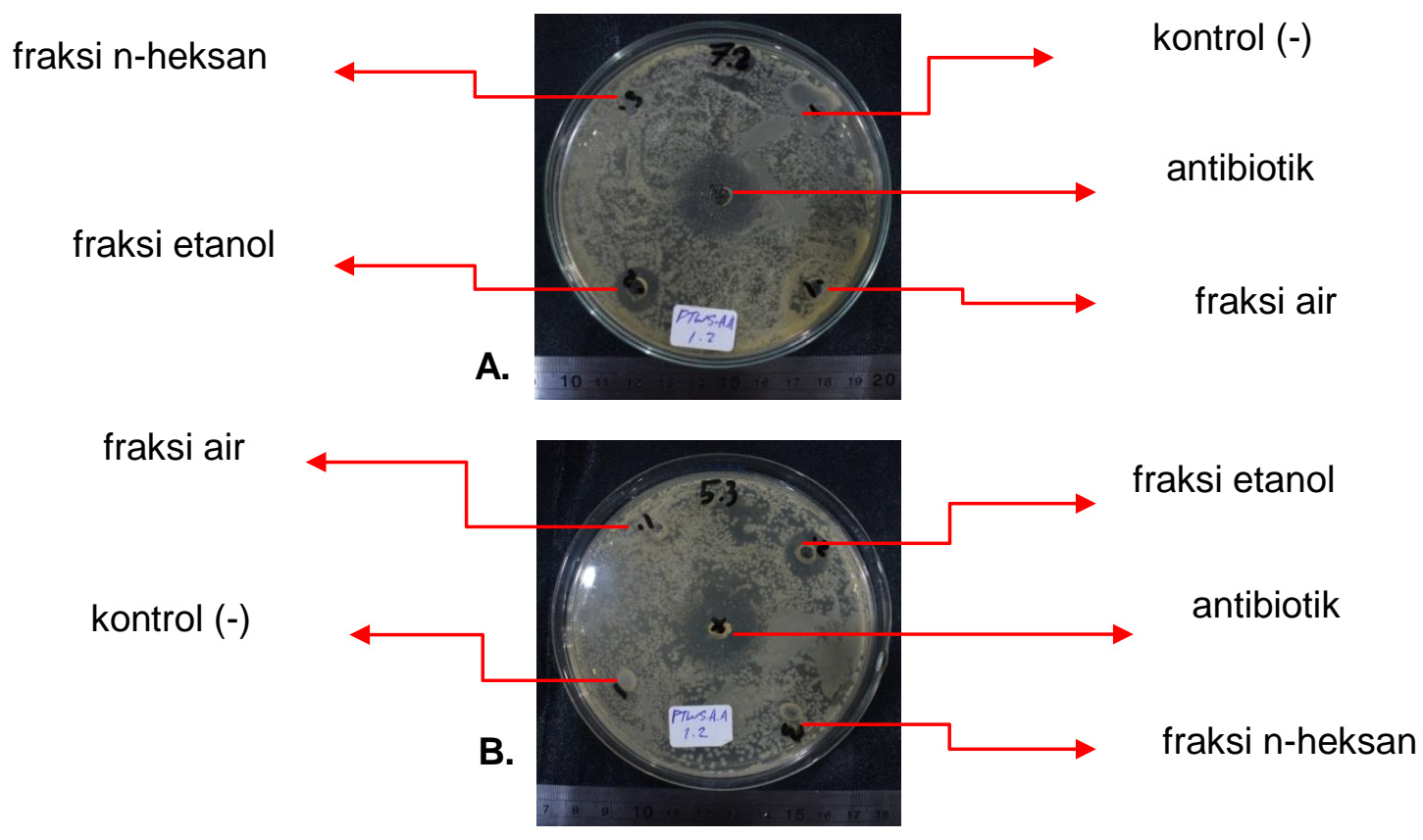

Gambar 6. Hasil pengujian aktivitas anti bakteri fraksi ekstrak PTWSA 1.2 terhadap bakteri $S$. aureus $(\mathrm{A})$ dan bakteri $E$. coli $(\mathrm{B})$.

Tabel. 4. Pengukuran daya hambat jamur pada fraksi ekstrak jamur PTWSAA 1.2 bakteri $S$. aureus dan E. coli.

\begin{tabular}{|c|c|c|c|c|c|c|c|c|}
\hline \multirow[t]{2}{*}{ PTWSAA1.2 } & \multicolumn{4}{|c|}{ S. aureus $(\mathrm{mm})$} & \multicolumn{4}{|c|}{ E. coli $(\mathrm{mm})$} \\
\hline & 1 & 2 & 3 & rata-rata & 1 & 2 & 3 & rata-rata \\
\hline fraksi air & 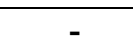 & - & - & - & - & - & - & \\
\hline fraksi etanol & 12 & 17 & 13 & $14.0 \pm 2.6$ & 14 & 13 & 13 & $13.3 \pm 0.6$ \\
\hline fraksi n-heksana & - & - & - & - & - & - & - & - \\
\hline kontrol negatif & - & - & - & - & - & - & - & - \\
\hline kontrol positif & 25 & 25 & 25 & $25.0 \pm 0$ & 25 & 25 & 25 & $25.0 \pm 0$ \\
\hline $\begin{array}{l}\text { Gambar } 7 . \\
\text { ya zona terang } \\
\text { I isolat jamur PT } \\
\text { ivasi bersama } \\
\text { ri } S \text {. aureus (P) } \\
\text { kontrol po } \\
\text { ukuran diamete } \\
\text { ak isolat jamur PT }\end{array}$ & $\begin{array}{l}\text { memp } \\
\text { di sek } \\
\text { TWSAA } \\
\text {-sama } \\
\text { TWSAA } \\
\text { sitifnya. } \\
r \quad \text { zona } \\
\text { TWSAA }\end{array}$ & $\begin{array}{l}\text { den } \\
1.2+\end{array}$ & & \multicolumn{5}{|c|}{$\begin{array}{l}\text { dikultivasi bersama-sama dengar } \\
\text { bakteri uji } S \text {. aureus terhadap bakteri uj } \\
\text { S. aureus dan bakteri E. coli dapa } \\
\text { dilihat pada Tabel } 5 \text {. Hasil penelitiar } \\
\text { pada isolat jamur ini menunjukkar } \\
\text { bahwa hanya pada fraksi etanol yang } \\
\text { memperlihatkan adanya zona hamba } \\
\text { sedangkan pada fraksi air dan fraksi } n \\
\text { heksan tidak memperlihatkan adanya } \\
\text { zona hambat. }\end{array}$} \\
\hline
\end{tabular}




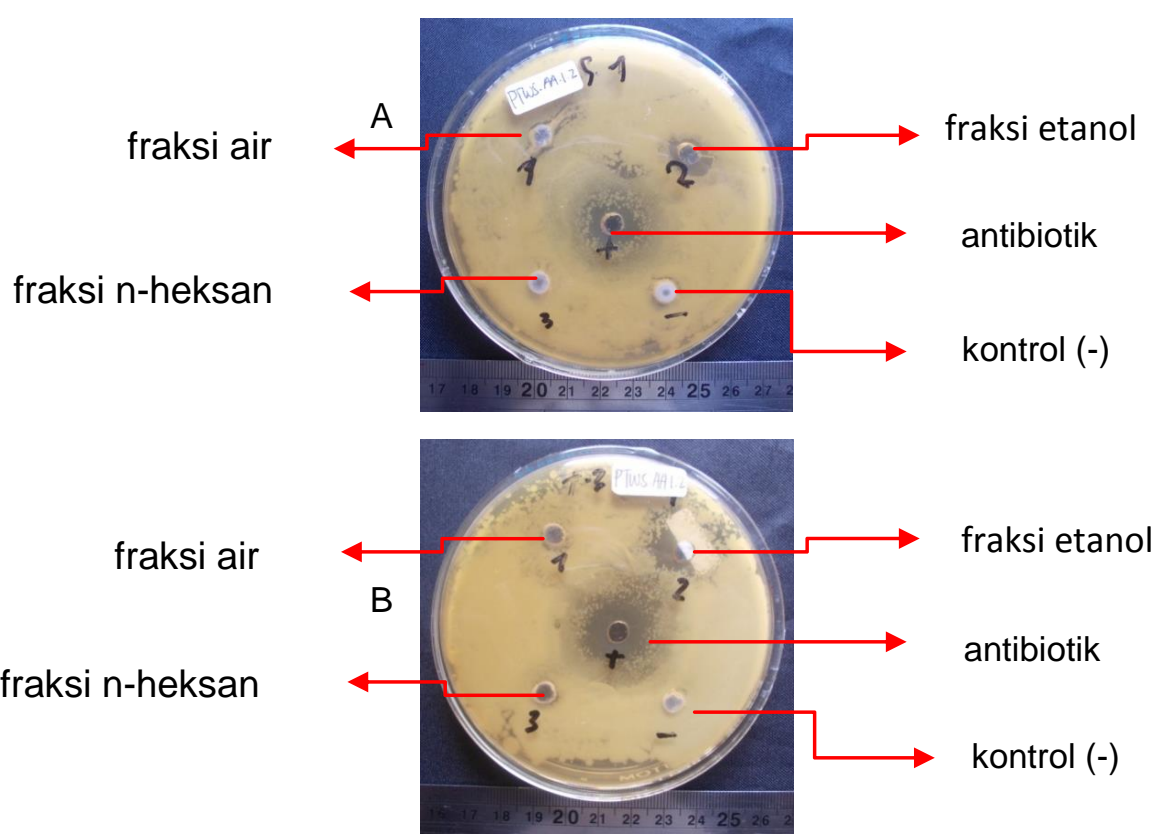

Gambar 7. Hasil pengujian aktivitas anti bakteri fraksi PTWSAA 1.2+S.a terhadap bakteri S. aureus (A) dan E. coli (B).

Tabel. 5. Pengukuran diameter zona hambat jamur pada fraksi ekstrak isolat jamur PTWSAA 1.2+S.a terhadap bakteri S. aureus dan E. coli

\begin{tabular}{lllllllll}
\hline PTWSAA & \multicolumn{4}{c}{ S. aureus $(\mathrm{mm})$} & \multicolumn{3}{c}{ E. coli $(\mathrm{mm})$} \\
\cline { 2 - 10 } 1.2+S.a & 1 & 2 & 3 & rata-rata & 1 & 2 & 3 & rata-rata \\
\hline fraksi air & - & - & - & - & - & - & - & - \\
fraksi etanol & 14 & 12 & 18 & $14.7 \pm 3.1$ & 12 & 13 & 10 & $11.7 \pm 1.5$ \\
fraksi n-heksana & - & - & - & - & - & - & - & - \\
kontrol negatif & - & - & - & - & - & - & - & - \\
kontrol positif & 30 & 24 & 24 & $26.0 \pm 2.4$ & 20 & 23 & 18 & $20.3 \pm 1.8$ \\
\hline
\end{tabular}

Gambar 8. memperlihatkan adanya zona terang di sekitar fraksi etanol isolat jamur PTWSAA 1.3 dan kontrol positifnya. Hasil pengukuran diameter zona hambat fraksi isolat jamur PTWSAA 1.3 terhadap $S$. aureus dan bakteri $E$. coli dapat dilihat pada

Tabel 6. Hasil penelitian pada isolat jamur ini menunjukkan bahwa hanya pada fraksi etanol yang memperlihatkan adanya aktivitas zona hambat sedangkan pada fraksi air dan fraksi n-heksan tidak menunjukkan adanya zona hambat.

Hasil pengujian aktivitas antibakteri dari setiap fraksi isolat jamur endofit yang diuji pada penelitian ini memperlihatkan senyawa aktif antibakteri dari tiap ekstrak jamur 


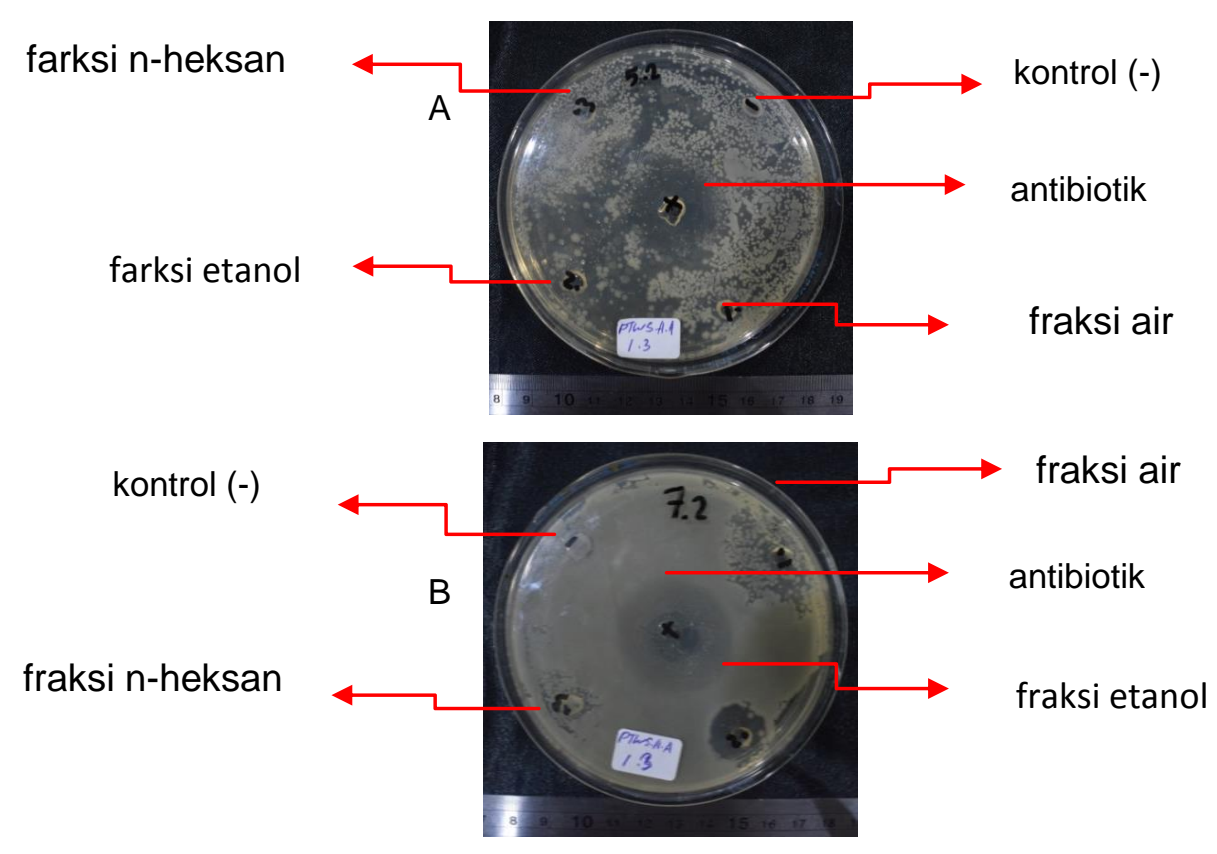

Gambar 8. Hasil pengujian aktivitas anti bakteri fraksi ekstrak PTWSAA 1.3 terhadap bakteri $S$. aureus (A) dan E. coli (B).

Tabel. 6. Pengukuran diameter zona hambat jamur pada fraksi ekstrak isolat jamur PTWSAA 1.3 terhadap bakteri S. aureus dan E. coli.

\begin{tabular}{lllllllll}
\hline PTWSAA 1.3 & \multicolumn{4}{c}{ S. aureus $(\mathrm{mm})$} & \multicolumn{3}{c}{ E. coli $(\mathrm{mm})$} \\
\cline { 2 - 9 } & 1 & 2 & 3 & rata-rata & 1 & 2 & 3 & rata-rata \\
\hline fraksi air & - & - & - & - & - & - & - & - \\
fraksi etanol & 14 & 14 & 14 & $14.0 \pm 0.0$ & 20 & 18 & 17 & $18.3 \pm 1.5$ \\
fraksi n-heksana & - & - & - & - & - & - & - & - \\
kontrol negatif & - & - & - & - & - & - & - & - \\
kontrol positif & 26 & 26 & 26 & $26.0 \pm 0.0$ & 26 & 26 & 26 & $26.0 \pm 0.0$ \\
\hline
\end{tabular}

endofit hanya berada pada fraksi etanol, sedangkan fraksi n-heksana dan fraksi air dari semua ekstrak jamur endofit yang diujikan pada penelitian ini tidak memperlihatkan adanya aktivitas penghambatan. Hal ini menunjukkan bahwa senyawa aktif antibakteri dari jamur endofit asal mangrove $S$. Alba merupakan senyawa yang bersifat semipolar.

\section{KESIMPULAN}

1. Sembilan isolat jamur endofit telah diisolasi mangrove $S$. alba yang tumbuh di Perairan Pantai Tanawangko Kabupaten Minahasa.

2. Pengujian awal menunjukkan lima isolat jamur memiliki aktivitas antibakteri terhadap isolat klinik $S$. aureus dan $E$. coli. Tiga isolat akar (PTWSAA 1.1, 1.2 dan 1.3) memperlihatkan aktivitas yang kuat pada kedua bakteri uji di atas. 
3. Induksi bakteri $S$. aureus pada kultur isolat jamur endofit PTWSAA 1.2 tidak memberikan pengaruh terhadap aktivitas antibakteri jamur tersebut.

4. Pengujian aktivitas antibakteri setiap fraksi isolat jamur endofit yang diuji pada penelitian ini hanya fraksi etanol yang memperlihatkan aktivitas penghambatan, fraksi air dan fraksi n-heksan tidak menunjukkan adanya zona hambat. Hal ini menunjukkan bahwa senyawa aktif antibakteri dari jamur endofit merupakan senyawa yang bersifat semipolar.

\section{DAFTAR PUSTAKA}

Aly, A. H., Debbab, A.,Proksch, P. 2011. Fungal endophytes: unique plant inhabitants withgreat promises. Applied Microbiology and Biotechnology. 90(6):1829-1845.

Bara, R., Aly, A. H., Wray, V., Lin, W., Proksch, P. Debbab, A. 2013 Talaromins and B,new cycli cpeptides from the endophytic fungus Talaromyces wortmannii.Tetrahedron Letters. . 54.(13.):686-1689.

Debbab, A., Aly, A.H., Ebel, R.A.E., Müller, W.E.G., Mosaddak, M., Hakiki,A., Ebel,R., Proksch, P., 2009. Bioactive secondary metabolites from the endophytic fungus Chaetomium sp. Isolated from Salvia officinalis growing in Morocco. Biotechnol. Agron. Soc.Environ.13(2): 229-234

Debbab, A., Aly, A. H., Edrada-Ebel, R., Wray, V., Pretsch, A., Pescitelli, G., Kurtan,T.,Proksch, P. 2012. New Anthracene Derivatives - Structure Elucidationand Antimicrobial Activity. European Journal of
Organic Chemistry (7): 1351-1359.

Debbab, A., Bara, R., Pretsch, A., Edrada Ebel, R., Wray, V., Pescitelli,G.,Kurtan,T.,Proksch, P. 2011. Newrare atropisomers: structure elucidation, absolute configuration and antimicrobial activity. Planta Med.

Dailey, L., Coombs, G. W., O'Brien, F. G.,Pearman, J. W., Christiansen, K., Grubb, W.B., Riley, T.V. 2005. Methicillinresistant Staphylococcusaureus, Western Australia. Emerging Infectious Diseases.

Ebrahim, W., Aly, A. H., Mándi, A., Totzke, F., Kubbutat, M. H. G., Wray,V.,Lin,W.H.,Dai,H.,Proksh, P., Kurtán,T., Debbab,A. 2012. Decalactonederivati vesfrom Corynespora cassiicola, an endophytic fungus of the mangrove plant Laguncul ariaracemosa.

European Journal of Organic Chemistry 2012(18): 3476-3484.

Ibrahim, S. R. M., Min, C. C., Teuscher, F., Ebel, R., Kakoschke, C., Lin, W., Wray, V., Edrada-Ebel, R.,Proksch, P. 2010. Callyaerins $\mathrm{A}-\mathrm{F}$ and $\mathrm{H}$, new cytotoxic cyclic peptides fromthe Indonesian marine sponge Callyspongiaaerizusa.

Bioorganic \& amp; Medicinal Chemistry18(14): 49474956.

Ola, A.R.B.; Thomy, D.; Lai, D.; BrotzOesterhelt, H.; Prolcsch, P. 2013. Inducing secondary metabolite production by the endophytic fungus Fusarium tricinctum through coculture with Bacillus subtilis. J. Nat. Prod. 76, 20942099. 
- Strobel, G., Daisy, B., Castillo, U., Harper,J. 2004. Natural Products from Endophytic Microorganisms. Journal of Natural Products 67(2):257-268. 